\section{Bubble-fusion engineer sues other scientists}

Purdue University in West Lafayette, Indiana, has sent federal authorities a report of its investigation into the work of nuclear engineer Rusi Taleyarkhan, Nature has learned.

Taleyarkhan is known for his claims to be able to produce fusion by collapsing bubbles in deuterated acetone by bombarding them with sound waves. His work had been subject to allegations of research misconduct, which Purdue had been investigating.

Taleyarkhan's lawyer, John Lewis of Lewis and Wilkins in Indianapolis, says that the final decision now lies with the inspectorgeneral of the Office of Naval Research in Arlington, Virginia. The office funded some of Taleyarkhan's research through grants. The Purdue report is confidential, but Taleyarkhan plans to contact the office to challenge the report's "accuracy, adequacy and completeness", says Lewis.

The engineer is also pursuing a defamation lawsuit, filed last month in Tippecanoe County in Indiana against scientists who questioned his claims of bubble fusion. The defendants include Purdue faculty members named in Nature articles, which helped trigger an institutional review. "The complaint filed is to clear up my reputation," Taleyarkhan says.

\section{US biodefence agency appoints first director}

The body set up last year to coordinate the US government's biodefence efforts has picked its first permanent director.

The Biomedical Advanced Research and Development Agency (BARDA) is to be headed by Robin Robinson, the Department of Health and Human Services announced last week. Robinson is currently deputy director of BARDA's influenza and emerging disease programme, and has overseen the development and stockpiling of vaccines against the $\mathrm{H} 5 \mathrm{~N} 1$ avian flu virus.

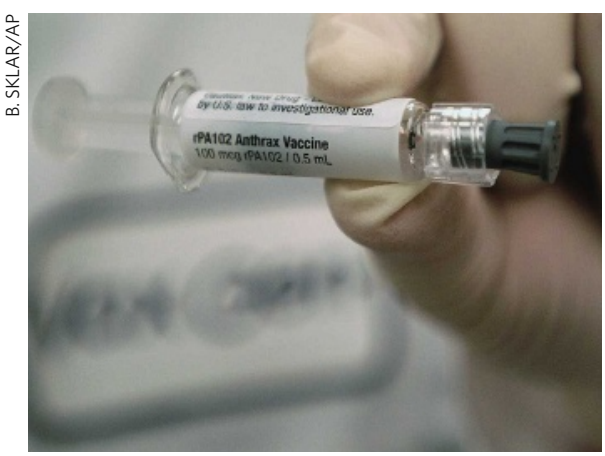

Anthrax scares in 2001 prompted Congress to boost US biodefence efforts.

\title{
Botanical art gallery opens in London
}

This image of the flowering house plant Medinilla magnifica by artist Margaret Ann Eden is now on display at the Royal Botanic Gardens at Kew in London.

It is part of an exhibition in the world's first year-round gallery dedicated to botanical art. The exhibition features works from Kew Gardens' 200,000-piece collection as well as from Shirley Sherwood, who has collected images from around 200 artists. The gardens' officials say that the Sherwood collection is possibly the most important private collection of modern botanical art in the world.

BARDA oversees Project BioShield, a \$5.6-billion effort to purchase biodefence countermeasures that has been criticized as a giveaway to industry (see Nature 431, $1023 ; 2004)$. It is the culmination of much congressional discussion over what to do about biodefence after the still-unsolved postal anthrax attacks of 2001 .

\section{Research assessment panel advised to destroy all notes}

All personal notes made by those conducting a massive assessment of university research in the United Kingdom should be destroyed, the organization in charge of the exercise has recommended.

Last week, the Times Higher Education published extracts from a letter written by Ed Hughes, head of the team managing the Research Assessment Exercise (RAE), which determines funding allocations for university departments. The letter recommended that members of assessment panels destroy all personal notes relating to their decisions.

However, the Higher Education Funding Council for England, which distributes the English portion of RAE-related funds, says that minutes of assessment meetings will still be published so that decisions can be scrutinized. The destruction of personal notes, the council says, is to prevent panel members being over-burdened with requests to publicly release their notes.

\section{GlaxoSmithKline does deal to develop microRNA drugs}

Pharmaceutical giant GlaxoSmithKline has negotiated a deal to develop drugs aimed at four microRNA molecules that have been linked to inflammatory diseases such as rheumatoid arthritis and inflammatory bowel disease. The agreement, with Regulus Therapeutics in Carlsbad, California, marks the first time a large pharmaceutical

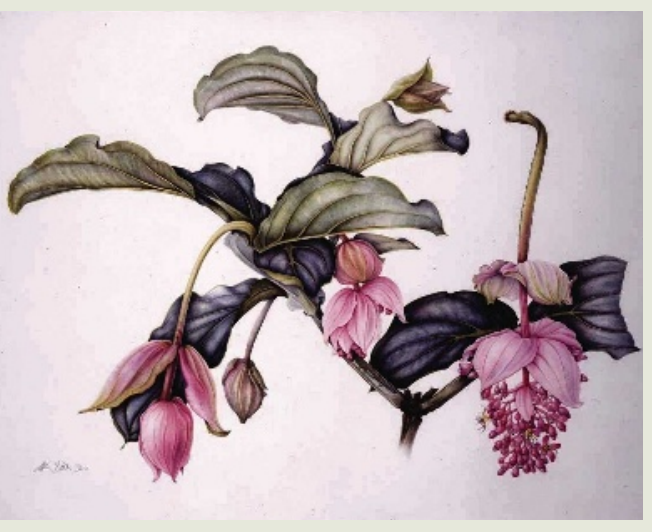

company has announced a collaboration that is exclusively focused on microRNAs, which silence genes by intercepting messenger RNA molecules.

Unlike small interfering RNAs that also work in this way, microRNAs usually downregulate expression of many genes at once. They have thus been associated with diseases involving multiple changes in gene expression, including cancer and viral infections.

Regulus will initially earn US\$20 million from the alliance, and then receive up to \$144.5 million more for each of the four microRNA targets for which it meets drugdevelopment milestones.

\section{UN ruling makes Australia an even bigger country}

Australia has become the first country to successfully claim an extension of its rights to the sea floor.

Resources and energy minister Martin Ferguson announced on Monday that the United Nations had extended the area of the country's continental shelf by 2.5 million square kilometres. "I'm pleased to announce that Australia, the largest island in the world, has been dramatically increased in size," he said.

The country's rights have been extended beyond the usual limit of 200 nautical miles (370 kilometres) in a number of areas, including those off the main Australian coast and number of smaller islands. This gives Australia exclusive rights to exploit any resources on the sea floor within this area, including oil and gas.

"It opens up a wealth of exploration entitlements," says Ferguson. "This is potentially a bonanza."

Other claims under the United Nations Convention on the Law of the Sea have been made by countries including Mexico, France and Great Britain. Contentious claims over the sea floor of the Arctic are expected from Russia, Canada and Norway. 